\title{
TEACHERS' PERCEPTION OF THE UTILIZATION OF INSTRUCTIONAL MATERIALS IN TEACHING SOCIAL STUDIES IN JUNIOR SECONDARY SCHOOLS IN CALABAR MUNICIPALITY, CROSS RIVER STATE, NIGERIA
}

DOMINIC IPUOLE OGBAJI

(Received 31, March 2017; Revision Accepted 28, June 2017)

\begin{abstract}
This study aimed at assessing teachers' perception of utilization of instructional materials in teaching social studies in junior secondary schools in Calabar Municipality of Cross River State, Nigeria. The study was guided by a research question based on the purpose of the study. The study adopted the survey research design. All of the fifty-three social studies teachers in public (junior) secondary schools in the area were used for the study. No sampling technique was used since all of the population of study was used. All the fourteen schools were used in the study. The research instrument is a four-point Likert type scale questionnaire with 10 items. Data collected were analyzed using descriptive statistics including mean, standard deviation and simple percentages. The analysis indicated that social studies teachers perceive instructional materials as necessary for effective teaching and learning.
\end{abstract}

KEYWORDS: Teachers, social studies, instructional materials, utilization

\section{INTRODUCTION}

Teaching is a profession, and all who desire to belong to the profession should be wellgrounded in the art of teaching, they need to be conversant with the philosophy guiding the educational enterprise of all countries in which they intend to practice, they need to have mastery of the subjects in which they specialized, or for which they are trained. A teacher is expected to plan his lesson(s) ahead of class time; it is during the planning stage that he will take care of the type of behaviours relevant to his teaching task, in view of his instructional objectives.

Bidwell (1973) in Uche and Enukoha (2005) defined teaching as a series of interactions between someone in the role of a teacher and someone in a role of a learner, with the explicit goal of changing one or more of the learner's cognitive states (what he knows or believes or his skills in performing or affective state (his attitudes, values or motives).
Instructional materials are also educational inputs and they are of vital importance in the successful implementation of any curriculum. Relevant and appropriate textbooks, visual and audio-visual materials like globes, charts, slides, maps, tapes etc are of paramount necessities in the teaching-learning process. Audio-visual materials supplement and consolidate what is read in the textbooks and journals.

Instructional materials are the relevant materials utilized by a teacher during social studies instructional process to facilitate teaching and learning and for the purpose of making the contents of the instructions more practical and less vague. It therefore follows that such resources may be both human and non-human provided they facilitate the acquisition and evaluation of knowledge, skills, attitude morals and values (Esu \& Inyang-Abia, 2004). Ordinary words or verbalization has been found to be inadequate for effective teaching. Instructional materials serve as a channel through which

Dominic Ipuole Ogbaji, Department of Social Science Education, University of Calabar, Calabar, Cross River State, Nigeria. 
messages, information, ideas and knowledge are disseminated more easily. The can therefore be manipulated, seen, heard, felt or talked about.

Instructional resources are anything or anybody the teacher turns to for help in his learning process (Esu \& Umoren, 1998). The interactive nature of some of the materials makes the learner part of the learning process. According to Esu and Inyang-Abia (2004) different types of instructional materials can be used in teaching any subject effectively. However, it is not all topics in social studies that require the same type and quantity of instructional materials. Esu and Inyang-Abia (2004), opined that as far as teaching of social studies is concerned, both textual and nontextual materials can be utilized effectively. Textual materials and non-textual materials refer respectively to all the print and non-print materials that are used by the teachers and learners for instructional processes. The print materials are the textbooks, magazines, periodicals, journals and newspapers, among others while the non-print materials include: charts, chalkboard, radio, television, pictures, films, videotapes, audiotapes realia, festivals and games, among others. Together, they assist the students in acquiring clear concepts of the subject matter of social studies. One of the biggest setbacks in the use of instructional materials is inadequate supply of instructional materials. The teachers and learners could improvise these materials especially when commercially-produced ones are not available.

However, the use of instructional materials in the teaching and learning of social studies is not only the issue, but also the appropriateness of the selected materials by the teacher to the topic at hand, which sometimes make the lesson lose effectiveness, thereby rendering the materials useless. These instructional materials are lacking in our secondary schools as a result, teachers take to chalk and talk as they have no visual or audiovisual materials which the students can see, touch, smell and hear in the process of teaching and learning. According to Dike (1989), instructional materials facilitate teaching and learning and when it is not available, learners cannot do well. This means that the utilization of instructional materials in teaching and learning process is vital to the educational goals and objectiveness.

\section{Literature review}

There are many literatures on the utilization of instructional resources for effective teaching and learning. Eshiet (1995) opined for effective teaching, the four elements vis curriculum, teacher, students and facilities have to be involved. Momoh (1980) carried out a research on the effect of instructional resources on students' performances in WASC examination in Kwara State. He correlated material resources with academic achievements of students in ten subjects. Data were collected from the subject teachers in relation to the resources employed in teaching in five schools. The achievement of students in WASC examinations for the past five years were related to the resources available for teaching each of the subjects he concluded that instructional materials have a significant effect on students' achievement in each of the subjects.

Moronfola (1982) in Okeme (2002) carried out a research in llorin local government area of Kwara state. Questionnaire was used to get data on the material resources available for the teaching of ten subjects in ten secondary school. WASC examination results for the past five years was collected and correlated to students' achievements in each of the ten subjects and to the amount of resources available for the teaching of the subjects. She also reported a significant effect of material resources on the academic achievements of students in each of the subjects.

Akolo (1978) in Okon (2004) conducted a survey of audio-visual materials for eight teachertraining colleges in Kwara state and for twelve teachers' colleges in Plateau State of Nigeria. The study considers such elements like equipment and materials owned by each of the selected teacher's utilization of equipment and materials owned and the number of teachers that hid some measure of audio-visual related training. The study revealed that there was under utilization of instructional equipment in some areas and non-utilization in other areas where the research was conducted.

Jekayinfa (2005) undertook a study on the use of instructional materials by social studies teachers in 7 states of Nigeria. The findings showed that the schools lacked quality textbooks, slides, audio visual equipment's and projectors, while maps, charts and globes were readily available. 
Purpose of the study examine the

The core objective of this study was to

1. Teachers' perception of the utilization of instructional materials in teaching social studies in Junior Secondary Schools in Calabar Municipality of Cross River State

\section{Research question}

The study was directed by the following questions:

1. What is the perception of teachers' on the utilization of instructional materials in teaching social studies in Junior Secondary Schools in Calabar Municipality of Cross River State?

\section{METHODOLOGY}

The study was carried out in Calabar Municipality of Cross River State, Nigeria. The study adopted the survey research design. The population of the study is made up of all the social studies teachers in junior secondary schools (public schools) in the study area. The Cross River State Secondary Education Board (2011) recorded a total of fifty-three (53) Social Studies teachers in Calabar Municipality. No sampling technique was used. since all the teachers were used, no need for sampling as all of the population of study was used. All the fourteen schools were used in the study. The research instrument is a four-point Likert type scale questionnaire with 10 items. The questionnaire, Social Studies Teachers' Perception of the Utilization of Instructional Materials Questionnaire (SSTPUIMQ) is made up of two sections - A \& B - to seek information on the demographic characteristics of the teachers and their perception of the utilisation of instructional material, respectively and the cut-off point is 3.00. Data collected were analyzed using descriptive statistics including mean, standard deviation and simple percentages.

\section{RESULT PRESENTATION}

Table 1: Demographic data of the respondents $(N=53)$

\begin{tabular}{|c|c|c|}
\hline Variables & Frequency & Percentage (\%) \\
\hline \multicolumn{3}{|l|}{ Sex: } \\
\hline Male & 15 & 25 \\
\hline Female & 38 & 75 \\
\hline Total & 53 & 100 \\
\hline \multicolumn{3}{|l|}{ Age: } \\
\hline $20-30$ years & 8 & 15 \\
\hline $31-40$ years & 23 & 43 \\
\hline $41-50$ years & 13 & 23 \\
\hline Above 50 years & 10 & 19 \\
\hline Total & 53 & 100 \\
\hline \multicolumn{3}{|l|}{ Qualification: } \\
\hline NCE & 14 & 26 \\
\hline B.ED & 28 & 53 \\
\hline M.SC & 11 & 21 \\
\hline Total & 53 & 100 \\
\hline \multicolumn{3}{|c|}{$\begin{array}{l}\text { Teaching experience: } \\
1-10 \text { years }\end{array}$} \\
\hline $11-20$ years & 20 & 38 \\
\hline $21-30$ years & 16 & 30 \\
\hline Above 30 years & 11 & 21 \\
\hline Total & 6 & 11 \\
\hline & 53 & 100 \\
\hline
\end{tabular}

Source: Authors' field survey, 2016. 
As shown in table 1,15 representing $\mathbf{2 5 \%}$ of the 100 respondents were males, $\mathbf{3 8}$ or $75 \%$ were females. The table also indicates that $8(15 \%)$ of the respondents were within the age bracket of 20-30 years, 23 (43\%) were between 31 and 40 years. Others between 41 and 50 years and above 50 years were 23 and 19 respectively. The table also reveals that some of the respondents were teaching with NCE/OND $(26 \%)$. Only $21 \%$ had a master's degree while $53 \%$ were bachelor's degree or HND holders.
Lastly, the table shows that majority of the respondents were teachers of 1-10 years (33), $11-20$ years (30), 21-30 years (27) and 31 years and above (20).

\section{Research question one:}

What is the perception of teachers' on the utilization of instructional materials in teaching social studies in Junior Secondary Schools in Calabar Municipality of Cross River State?

Table 1 Mean rating and standard deviation of perception of teachers' on the utilization of instructional materials in teaching social studies in Junior Secondary Schools in Calabar Municipality of Cross River State.

\begin{tabular}{|c|c|c|c|c|c|c|c|c|}
\hline Item no. & Item description & SA & A & D & SD & $\mathbf{x}$ & SD & Decision \\
\hline 1. & $\begin{array}{l}\text { Social studies instructional materials are in short } \\
\text { supply in Calabar municipality }\end{array}$ & 23 & 20 & 7 & 3 & 4.00 & 1.16 & Accepted \\
\hline 2. & $\begin{array}{l}\text { The use of instructional materials makes lesson } \\
\text { delivery easy }\end{array}$ & 21 & 19 & 9 & 4 & 4.08 & 1.44 & Accepted \\
\hline 3. & $\begin{array}{l}\text { The effectiveness of instructional materials is } \\
\text { dependent on their relevance to topic under study }\end{array}$ & 19 & 18 & 11 & 5 & 2.78 & 1.11 & Rejected \\
\hline 4. & $\begin{array}{l}\text { All social studies topic can be taught effectively } \\
\text { even without instructional material }\end{array}$ & 10 & 12 & 23 & 18 & 3.83 & 1.36 & Accepted \\
\hline 5. & $\begin{array}{l}\text { Improvisation is not necessary if instructional } \\
\text { material is unavailable }\end{array}$ & 11 & 7 & 17 & 18 & 4.02 & 1.45 & Accepted \\
\hline 6. & $\begin{array}{l}\text { I judiciously utilise instructional materials even } \\
\text { when they are available in minimal quantity }\end{array}$ & 10 & 8 & 22 & 13 & 2.99 & 1.21 & Rejected \\
\hline 7. & $\begin{array}{l}\text { The lack of utilisation of instructional material is the } \\
\text { bane of the actualisation of social studies objectives } \\
\text { in Calabar municipality }\end{array}$ & 17 & 22 & 8 & 6 & 3.87 & 1.33 & Accepted \\
\hline 8. & $\begin{array}{l}\text { Instructional materials are in short supply in } \\
\text { secondary schools in Calabar Municipality }\end{array}$ & 21 & 19 & 10 & 3 & 4.14 & 1.51 & Accepted \\
\hline 9. & $\begin{array}{l}\text { Community resources are widely used in Calabar } \\
\text { municipality }\end{array}$ & 6 & 8 & 23 & 16 & 2.97 & 1.01 & Rejected \\
\hline 10. & $\begin{array}{l}\text { It is sometimes difficult to use instructional material } \\
\text { in the teaching process }\end{array}$ & 16 & 22 & 10 & 5 & 4.09 & 1.43 & Accepted \\
\hline \multicolumn{6}{|c|}{ Cluster mean and standard deviation } & 3.67 & 1.30 & Accepted \\
\hline
\end{tabular}

Data presented on table 4.1 .1 showed that the mean ratings of items $1-10$ are 4.00 , $4.08,2.78,3.83,4.02,2.99,3.87,4.14,2.97$, and 4.09 respectively with the corresponding standard deviations of $1.16,1.14,1.11,1.36$, $1.45,1.21,1.33,1.51,1.01$ and 1.43 . The result of the analysis showed that items $1,2,4,5,7,8$ and 10 were rated above the cut-off point of 3.0 and thus accepted while item 3, 6 and 9 were rated below it and rejected. Moreover, the cluster mean of 3.68 and standard deviation of 1.30 was found to be above the cut-off point of 3.00 . This implies that the respondents are affirmative to teachers' perception of the utilisation of instructional materials in the teaching of social studies in Calabar Municipality, Cross River State, Nigeria.

\section{Discussion of findings}

Data were collected to assess teachers' perception of the utilisation of instructional materials in social studies in Calabar municipality. The analysis of the data collected by means of mean and standard deviation, teachers 
generally agreed that instructional material is instrumental to the effectiveness of the instructional environment and indeed the entire teaching and learning environment. The study shows that even when teachers are reluctant to utilise instructional materials for their lessons, community resources and others resources are rarely available. Furthermore, the study indicated that the dearth or utilisation of instructional materials in social studies is the bane of the realisation of social studies objectives in the area of study.

This finding gives credence to previous works. Firstly, Jekayinfa (2005) has shown that social studies instructional materials are in short supply. Meziobi, Nwosu and Meziobi (2013) maintain that social studies teachers do not contemplate at all, let alone use, community resources in social studies pedagogy. The fact that social studies teachers are reluctant to use instructional materials in their lessons is justified by Meziobi, Nwalado \& Igbokwe (2015), who identified a number factor that favours this anomaly. Such factors mentioned include ignorance, lack of enthusiasm and lack of operational know-how on the part of the teacher.

\section{CONCLUSION/RECOMMENDATIONS}

The social studies teacher is at the implementation stage of social studies curriculum. However, his effectiveness in delivering the lesson objective is hampered by a perceived and actual unavailability of instructional materials. It is perceived to be unavailable in the sight of most teachers in the sense that they do not intend to utilise their creative ability by improvising. Nevertheless, social studies teachers perceive instructional materials as necessary for effective teaching and learning process.

Government should provide adequate instructional facilities to schools to facilitate effective teaching and learning of social studies.

Where there is non social studies teachers should improvise instructional materials from the local environment to improve teaching and learning in the class room .

Philanthropists, non-governmental organization should assist the government in making financial provision for the funding of social studies instructional materials particularly in secondary schools and social studies teachers should be trained on how to use instructional materials through workshops and seminars.

\section{REFERENCES}

Akolo, J. P., 1998. "Visual Aids and the past Primary Teacher". A paper presented to the first Audio-Visual workshop for selected teachers, inspector of education and Audio-Visual officers in Ilorin Kwara State.

Anyanwu, J. M., 2003. "The Effectiveness of Instructional Materials in teaching of Social studies in some selected post Primary School in our Owerri Educational Zone Imo State (B. ed) Research project unpublished.

Bidwell, Charles E., 1993. "The Social Psychology of Teaching". In Robert M. W. Travers (ed) Second Handbook of Research on Teaching. Chicago: Rand MCNally College Publishing Co.

Coombs, P. H., 1990. The world Education Crisis: A systems analysis New York: Oxford University Press.

Dike, H. I., 1989. Strategies for producing instructional materials Owerri: Joewam Publishers.

Esu AEO \& Inyang -Abia., 2004. Social Studies Technologies, Methods \& Media PortHarcourt: Double Diamond Publication.

Esu, A. E. O., Enukoha, O. I and Umoren, G. U., 2006. Curriculum Development in Nigeria for colleges and Universities Calabar: Mediamark Associates

Jekayinfa, A. A., 2005 "Availability of Resources for the Implementations of Social Studies Curriculum at the Senior Secondary School level in Nigeria". African Journal of Education Studies. 3 (1)

Meziobi, D. I., Nwalado, E. N and Igbokwe, U. L., 2015. Social Studies and Resources. In Edinyang, S. D. \& Effiom, V. N. (eds) Social Studies Material \& Resources. Calabar: Maesot \& Company

Meziobi, K. I., Nwosu, A and Meziobi, K. S., 2013. Community resources: The least thought about and utilised in Social Studies 
pedagogy in Nigeria. Rivers Journal of Social Studies 8(6): 1 -14.

Moronfola, B., 1999 "Effect of instructional resources on the Academic Achievement of Secondary school in llorin Local Government of Kwara State. Unpublished M.Ed Thesis.

Okeme, B., 2002. Instructional Technology Specialists and curriculum work. Journal of research on technology in education.
Onyejemezi, D. A., $1996 . \quad$ Resources development in education Strategies for schools in Nkpa" M. A. (ed), contemporary issues in Nigeria Education. Awka: Mekslrik publishing company Itd.

Popoola, T. A., 1998. An investigation in to the relationship between instructional resources and students academic performance in secondary schools, in Abeokuta local Government Area of Ogun State of Nigeria. An unpublished M.Ed Thesis. 